Kreshnik Hakrama ${ }^{1 *}$, Genti Guxho², Eldi Liço ${ }^{3}$

${ }^{1}$ Metrology, Kashar, Albania, ${ }^{2}$ Polytechnic University of Tirana, Mechanical Engineering Faculty, Tirana, Albania, ${ }^{3}$ University of Tirana, Natural Sciences Faculty, Tirana, Albania
Scientific paper

ISSN 0351-9465, E-ISSN 2466-2585

UDC:620.187

doi: $10.5937 /$ ZasMat1702222H

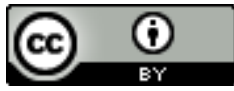

Zastita Materijala 58 (2)

222 - 227 (2017)

\title{
Morphological and chemical study of recycled synthetic rubber tire crumbs by using scanning electron microscopy and energy dispersive analysis
}

\begin{abstract}
The present paper aims to investigate the structure and chemistry of recycled synthetic rubber tire crumbs. It comprises the microscopic structure description of rubbers, separation of component phases and determination of chemical elements of additives that we use. For this purpose we have used scanning electronic microscope (SEM) JEOL6380LV equipped with the system of dispersive of energy spectroscopy (EDS). The rubber samples were collected from different mini soccer fields in Albania that use synthetic grass, where the rubber is used as filler increasing the stability and the elastic properties of the synthetic grass. The samples were analyzed as crumbs, as taken from the fields. Crumb metal infill a sustainable metal free and should not contain liberated fibers in an amount that exceed $0.01 \%$ of the total weight $f$ crumb rubber. So far, we have studied 7 different crumbs of recycled synthetic rubber tire. Through the images provided by SEM we could study the microstructure of our samples. Also, after conducting an EDX spectrum analysis, we observed additives in the recyclable materials.
\end{abstract}

Keywords: recycled rubber, SEM, EDS, synthetic a artificial grass, EDX, additives.

\section{INTRODUCTION}

Crumb rubber infill, made from reclaimed tires, is a popular infill option for many synthetic turf fields. It has been safety utilized since being introduced in 1997, and in playgrounds and tracks for much longer. This resilient material provides enhanced durability and safety. Its use in synthetic turf sports fields and landscapes has also kept more than 105 million used tires out of landfills. Crumb rubber has been critically examined and studied since the late of 1980's. Science has proven to be safe for children and people for all ages [1-4].

Recycling of scrap tires until the 1960's in the US can be taken as an example; about half of the manufactured automobile tires used to be recycled since only synthetic or natural rubber was used in the tire manufacturing process and tires could have been directly used without major processing. Recycling of used tires was further encouraged by

\footnotetext{
${ }^{*}$ Corresponding author: Kreshnik Hakrama

E-mail: k_hakrama@yahoo.com

Paper received: 12. 03. 2017.

Paper accepted: 26. 04. 2017.

Paper is available on the website:

www.idk.org.rs/journal
}

the fact that these materials were also expensive. The increasing use of the synthetic rubber, however, lowered the manufacturing costs and reduced need for recycling [5].

Rubber is produced from natural or synthetic sources. Natural rubber is obtained from the milky white fluid called latex, found in many plants; synthetic rubbers are produced from unsaturated hydrocarbons. Recycled tire material, or "tire crumb," is used as a component of many recreational fields, including artificial turf fields. These crumbs constitute as much as $90 \%$ (by weight) of the fields. The tire crumbs are approximately the size of grains of coarse sand, and they are made by shredding and grinding used tires. Tire crumb materials are spread two to three inches thick over the field surface and packed between ribbons of green plastic used to simulate green grass [3]. Synthetic rubbers are classified into general purpose rubbers and special purpose rubbers.

By using rubber particles in applications such as soccer fields offers several benefits, including decreasing and sports injuries. Advantages in artificial terrain lie in rubber ability to withstand 
aggravated climatic conditions, even during or immediately after a rain storm [2]. The granulated rubbers used as infill material for artificial turf are recycled mostly from the tires of cars, trucks and bicycle [6]. These tires are supposed to be abrasion resistance, aging resistance, temperature resistance, resistance to oxygen and chemicals therefore are added fillers like carbon black during vulcanization with sulfur [2]. As such it is very important to know what kind of additives and to know are the recycled. Therefore the purpose of this paper

Table 1. List of the analyzed rubber sample

Tabela 1. Lista analiziranih gumenih uzoraka

\begin{tabular}{|l|c|c|c|c|c|c|c|}
\hline \multicolumn{1}{|c|}{ Sample } & G-1 & G-2 & G-3 & G-4 & G-5 & G-6 & G-7 \\
\hline Color & White & Green & Black & Black & Black & Black & Black \\
\hline \multirow{2}{*}{ Shape } & Granule & Granule & Granule & Granule & Granule & Granule & Granule \\
& $2.5 \mathrm{~mm}$ & $0.8 \mathrm{~mm}$ & $0.8 \mathrm{~mm}$ & $0.8 \mathrm{~mm}$ & $0.8 \mathrm{~mm}$ & $2.0 \mathrm{~mm}$ & $1.0 \mathrm{~mm}$ \\
\hline
\end{tabular}

\section{METHODS}

For morphological study of the surface of the plastic materials a SEM JEOL6380LV scanning electron microscope was used (National Technical University of Athens, Greece). High resolution images were acquired, either in the secondary electron mode (SEM) for topography, or the backscattered electron mode (BSE) to reveal possible compositional variation.
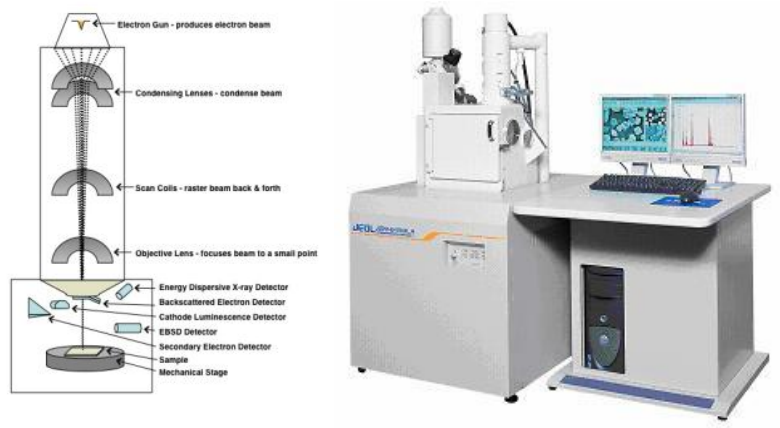

Figure 1. (left) scheme of principles of SEM and (right), image of SEM-EDS instrument used

Slika 1. (levo) šema SEM, (desno) slika korišćenog SEM-EDS instrumenta

\subsection{Scanning Electronic Microscope (SEM)}

SEM is equipped with a X-ray microanalysis system (EDS of Oxford Instruments). EDS stands for "Energy Dispersive Spectroscopy" and it is based on X-rays emitted from a sample during electron irradiation. With this instrument chemical analysis, either qualitative or quantitative, can be performed [4,7]. In this case, only qualitative analyses are given because additives are impregnated in the polymeric material and mixed analyses cannot be avoided. is to investigate the components of granulated synthetic rubbers used in artificial turf. The samples are randomly chosen from different fields and for investigation Scanning Electronic Microscope (SEM).

\section{MATERIALS}

In this research were closen seven recycled synthetic rubber tire crumbs, collected from soccer fields in Albania, different in form and color.
The rubber samples were analyzed in their original form, as taken from the soccer field in Albania.

After performing the SEM analyses for all seven samples a spectrum was taken as show a figures. Consequently, the provided chemical analyses are shown in the form of spectra [7].

In Figure 2, stains with a lighter color are easily noticed in the BSE image on the surface of the crumb. These stains witness the presence of foreign elements in the matrix of rubber. Chemical analysis over a number of such stains reveals minor quantities of other elements, such as zinc, silicon, potassium, magnesium, iron, and sulfur. Zinc oxide, together with stearic acid, plays an important role in vulcanization chemistry, called activators. These compounds react together and with accelerators to form a zinc sulfurating compound, which in turn is the key intermediary in adding sulfur to a diene elastomer and creating sulfur interlinks.

Table 1. Chemical analysis compositions of Rubber Tabela 1. Hemijska analiza gume

\begin{tabular}{|l|c|c|}
\hline \multicolumn{1}{|c|}{ Element } & Weight\% & Atomic\% \\
\hline $\mathrm{CaO}$ & 2.75 & 4.37 \\
\hline $\mathrm{SiO} 2$ & 6.32 & 9.05 \\
\hline $\mathrm{Al}_{2} \mathrm{O}_{3}$ & 3.65 & 5.03 \\
\hline $\mathrm{Fe}_{2} \mathrm{O}_{3}$ & 48.75 & 58.76 \\
\hline $\mathrm{MgO}$ & 2.75 & 4.37 \\
\hline $\mathrm{SO}_{3}$ & 6.32 & 9.05 \\
\hline $\mathrm{K}_{2} \mathrm{O}$ & 3.65 & 5.03 \\
\hline $\mathrm{Zn} \mathrm{K}$ & 38.53 & 22.78 \\
\hline
\end{tabular}

\section{RESULTS}



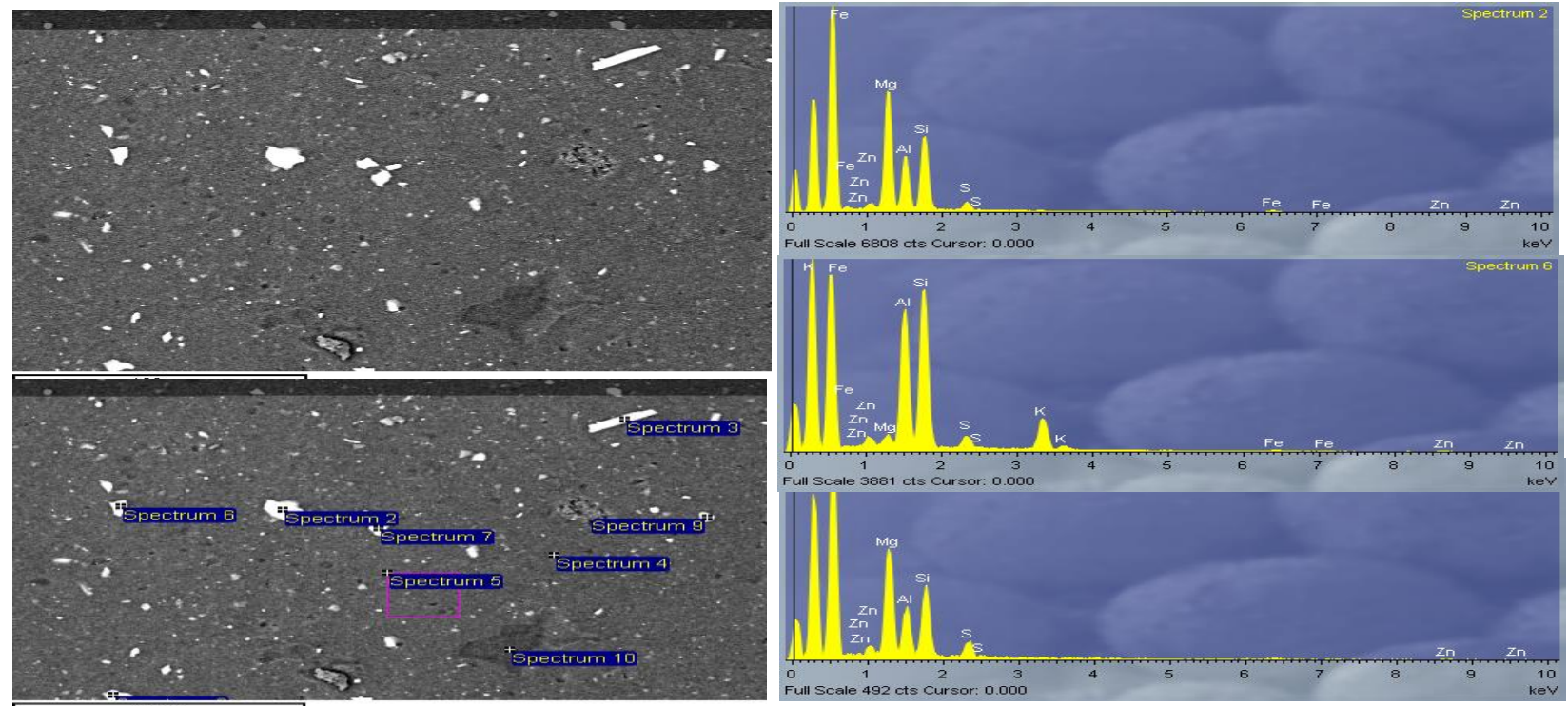

Figure 2. (left) Micrographs of first rubber crumb with the interest areas focused, (right) $X$-ray spectra of rubber

Slika 2. (levo) Mikrografski snimak prvog uzorka gume sa opiljcima i karakteristična mesta, (desno) X-ray spektar gume

Reinforcing filler used in rubber with particles of similar shape and size is finely divided silica. Magnesium oxide is necessary to give scorch resistance during vulcanization, mixed with zinc oxide. Magnesia is included in the formulation to act as a scavenger for the chlorine atom also. Iron

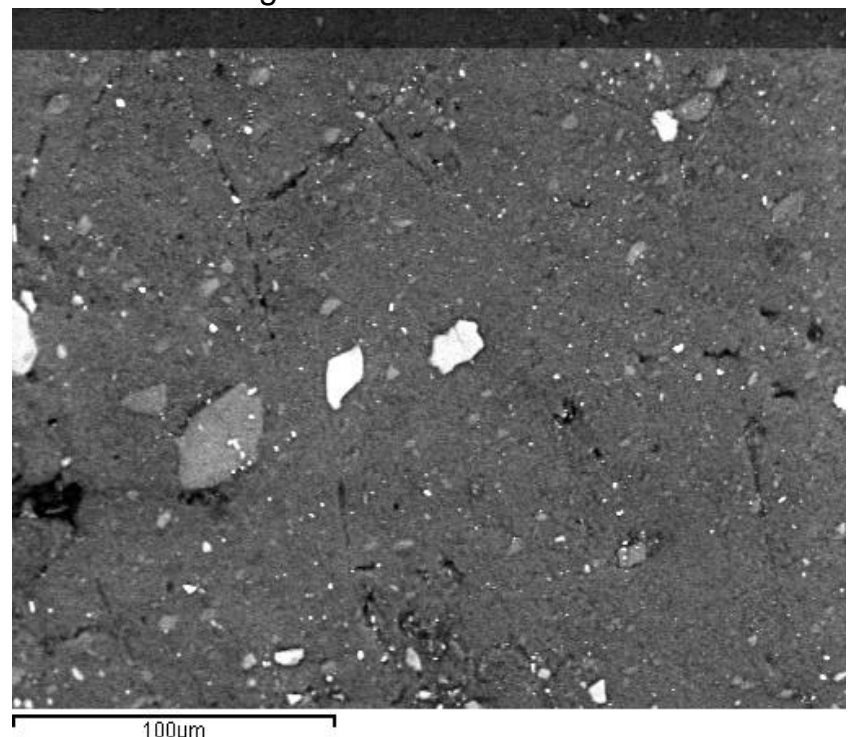

oxides were found to be active fillers which improve mechanical and magnetic properties of the elastomers. Aluminum silicates are good reinforcing fillers, they give comparatively harder vulcanizates than other fillers, such as calcium silicates [8].

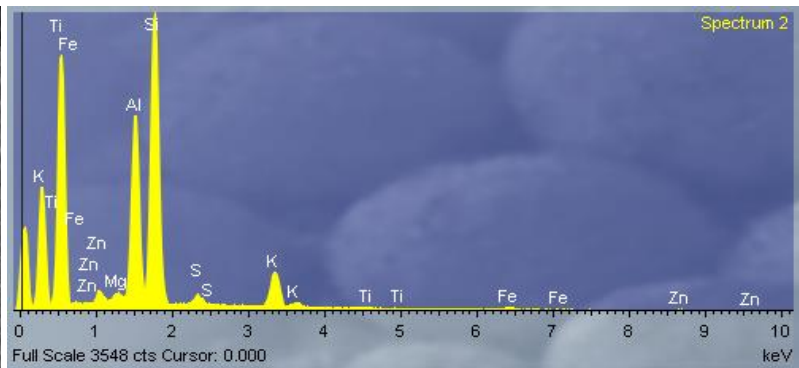

Figure 3. (left) Micrographs of second rubber with crumb, (right) X-ray spectra of 2nd rubber

Slika 3. (levo) Mikrografski snimak drugog uzorka guma sa opiljcima, (desno) X-ray spektar drugog uzorka gume

In figure 3, the BSE image shows the presence of many foreign elements inside the matrix of the second rubber crumb. Chemical analysis over a number of such stains reveals quantities of chemical elements, such as silicon, aluminum, potassium, iron, magnesium, and sulfur. The presence of oxygen shows that additives are added as metal oxides. Titanium and iron oxides are used in many processes as pigments. Microholes and microclusters are present in this sample. 

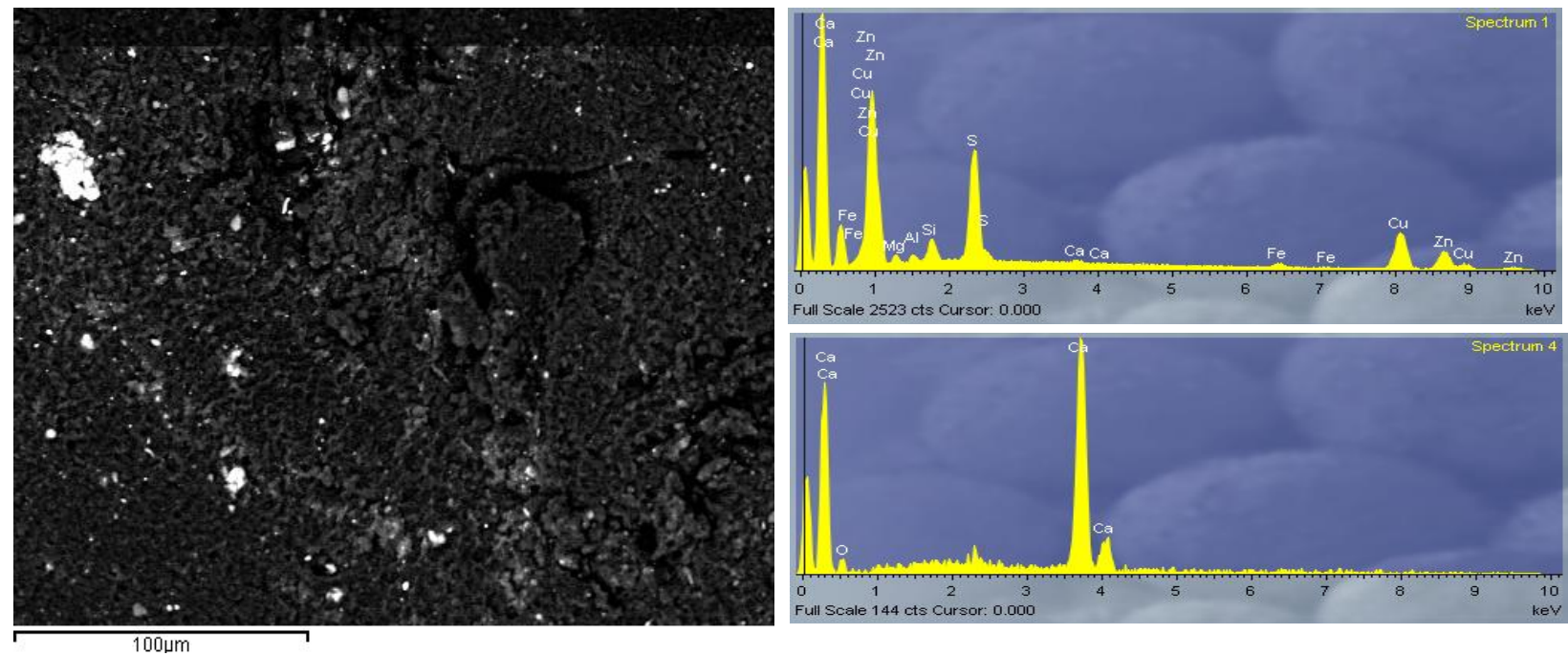

Figure 4. (left) Micrographs of third rubber with crumb, (right) X-ray spectra of 3rd rubber

Slika 4. (levo) Mikrografski snimak trećeg uzorka guma sa opiljcima, (desno) X-ray spektar trećeg uzorka gume

The SEM image of the $3^{\text {rd }}$ rubber crumb is show in the figure 4 . As we can see from the X-ray spectrum, calcium, zinc cuprum, sulfur, iron and oxygen are identified. Calcium Oxide is used in several elastomer recipes to act as a desiccant (meaning it absorbs and breaks-down $\mathrm{H} 20$ ), and to consequently reduce the risk of porosity in the cured, end product $[9,10]$.
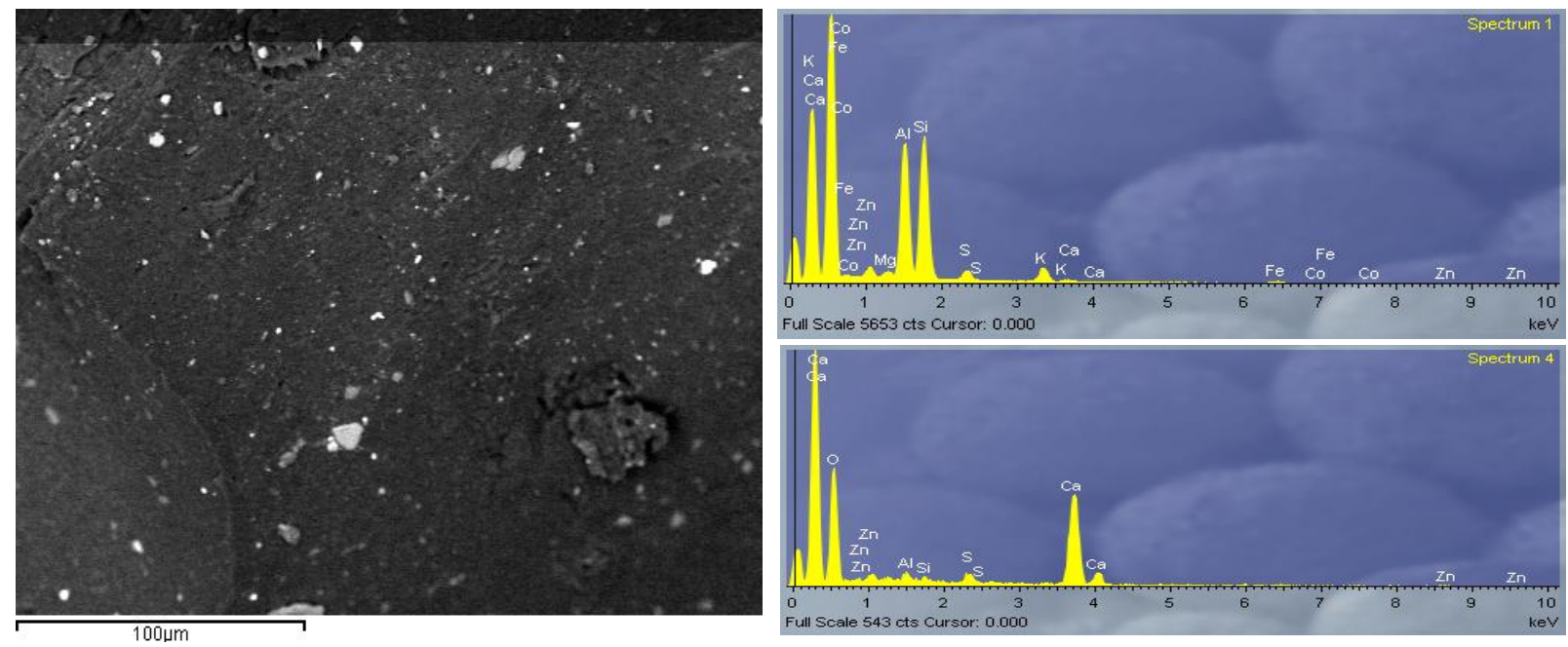

Figure 5. (left) Micrographs of forth rubber with crumb, (right) X-ray spectra of 4th rubber

Slika 5. (levo)Mikrografski snimak četvrtog uzorka guma sa opiljcima, (desno) X-ray spektar četvrtog uzorka gume

The SEM image of figure 5 shows the spread of additives on forth rubber crumb such as silicon, aluminum, zinc, magnesium, calcium and potassium. The presence of these elements is due to the mainly use of mineral fillers such as talc of mica, which are used as lubricant and dusting agents. Also, we observe some microdefects of the microstructure of the rubber.

The SEM image figure 6 shows the spread of additives on fifth rubber crumb such as silicon, aluminum, zinc, magnesium, oxide and potassium.
The SEM image figure 7 shows the spread of additives on sixth rubber crumb such as calcium, aluminum, silicon, chlorine, zinc, magnesium, calcium and potassium. In this case, the presence of chlorine may determine the rubber as chlorinated. Chlorinated rubber is a type of powdery thermoplastic resin of high hardness. It is considered an environmentally friendly resin. With excellent adhesiveness, it can be used for chemicals and abrasives. Due to its high chlorine content, it is incombustible and therefore used for making fireproof and anti-corrosion paint. Its films exhibit excellent resistance to corrosive influences. 

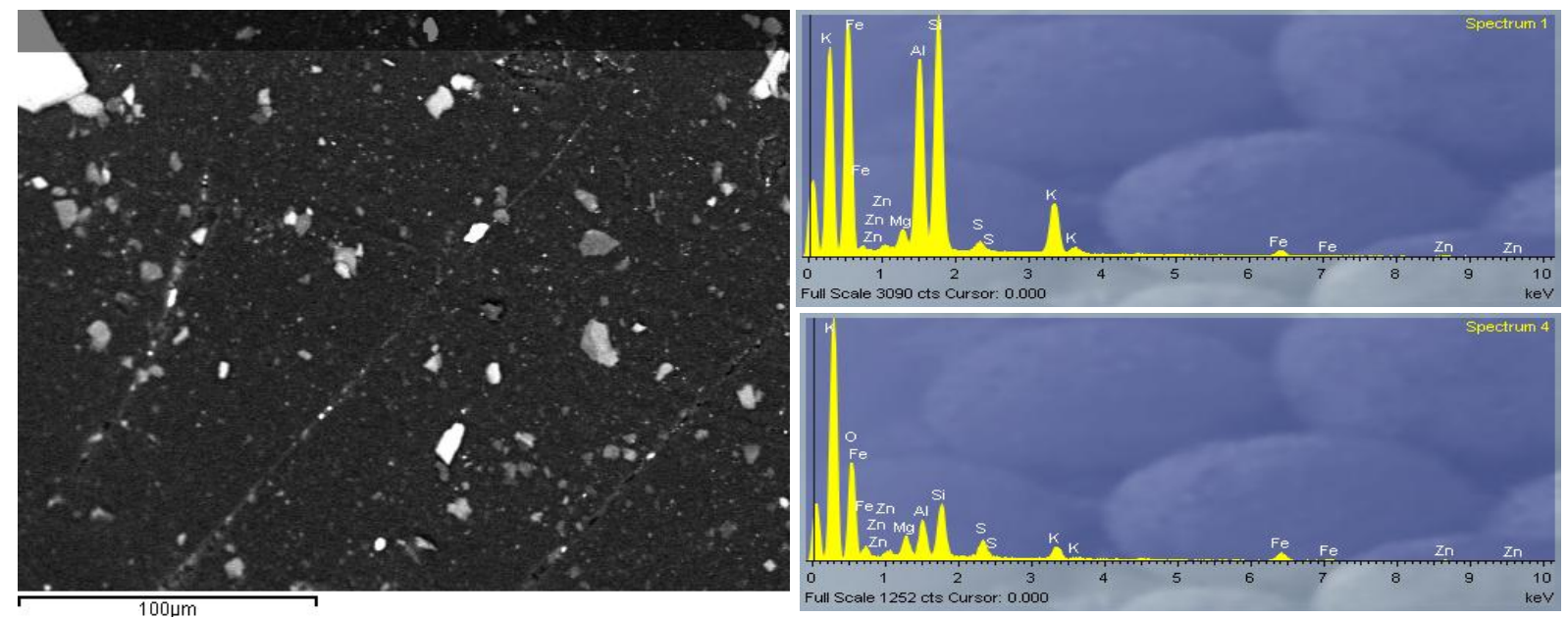

Figure 6. (left) Micrographs of fifth rubber with crumb, (right) X-ray spectra of 5th rubber Slika 6. (levo) Mikrografski snimak petog uzorka guma sa opiljcima, (desno) X-ray spektar petog uzorka gume

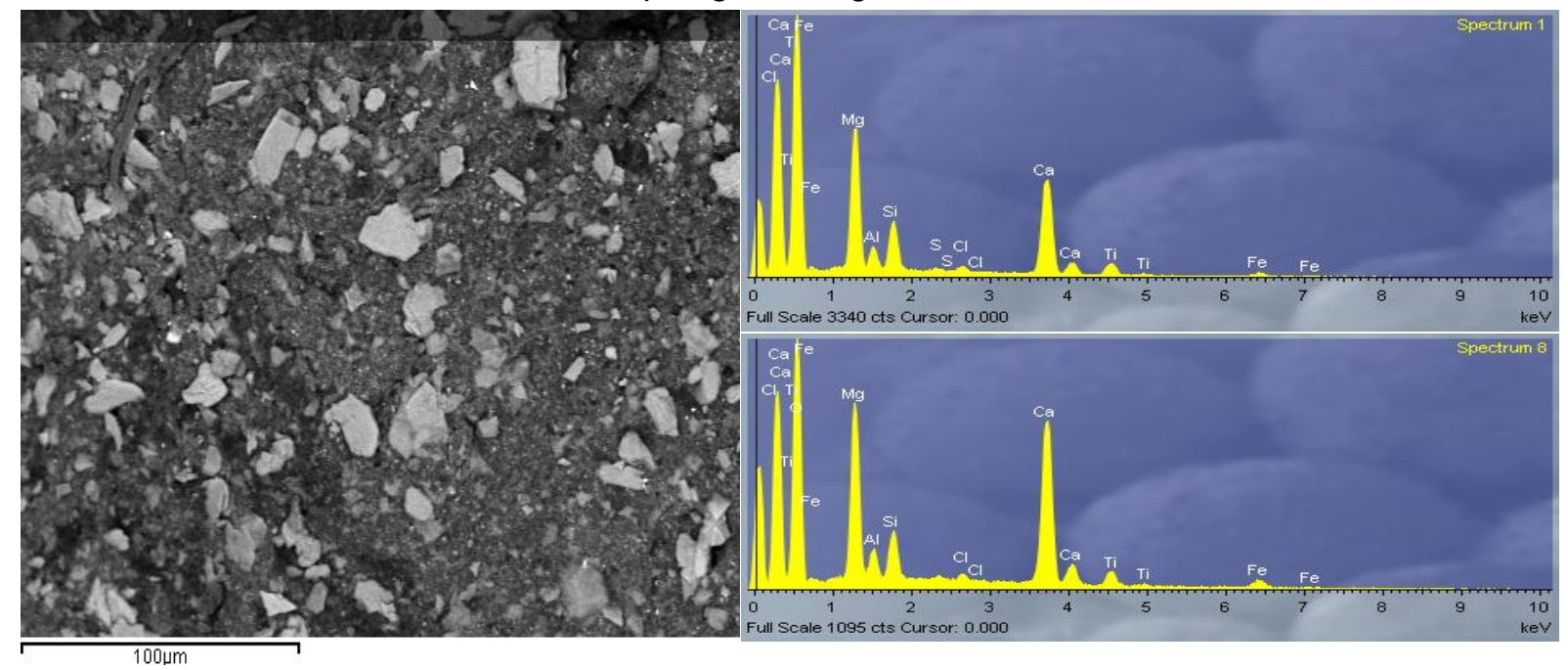

Figure 7. (left) Micrograph of sixth rubber with crumb, (right) X-ray spectra of 6th rubber Slika 7. (levo ) mikrografski snimak šestog uzorka guma sa opiljcima, (desno) X-ray spektar šestog uzorka gume
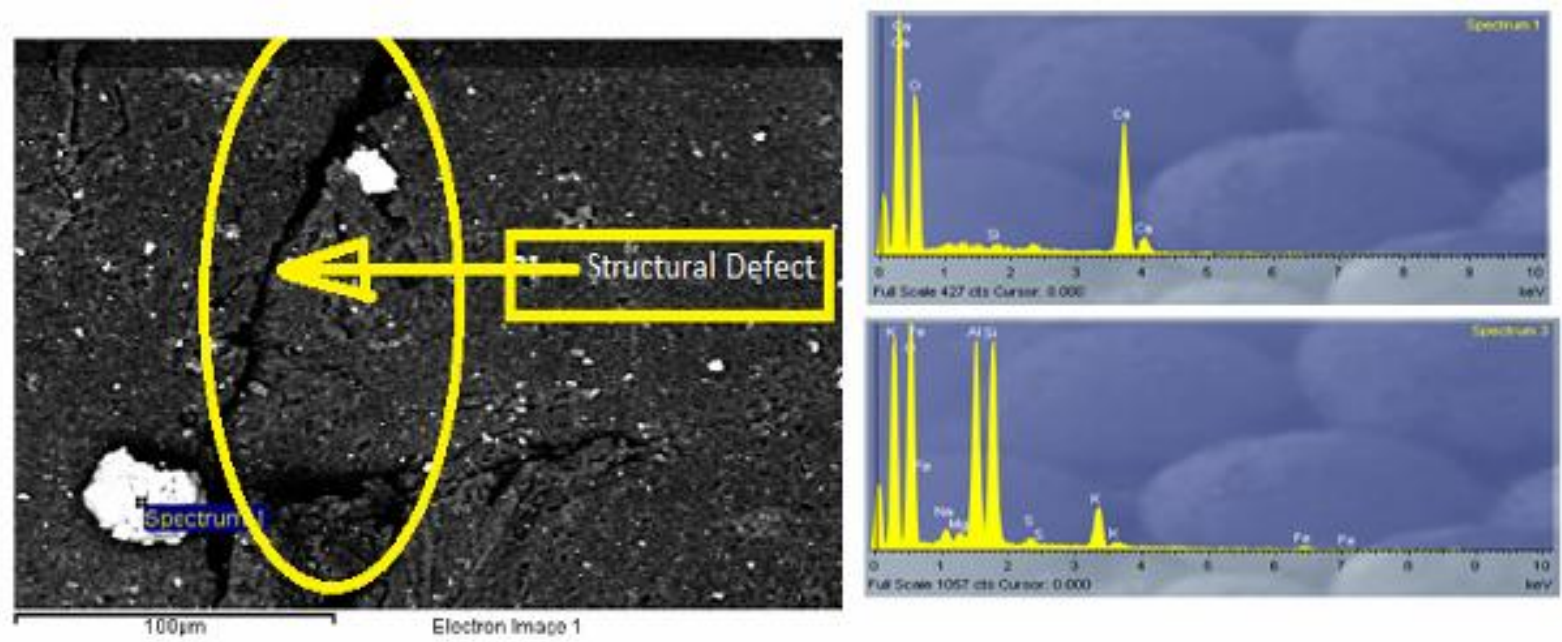

Figure 8. (left) Micrograph of seventh rubber with crumb, (right) X-ray spectra of 7th rubber Slika 8. (levo) mikrografski snimak sedmog uzorka guma sa opiljcima, (desno) X-ray spektar sedmog uzorka gume 
The SEM image figure 8 shows the spread of additives on seventh rubber crumb such as calcium, oxide, aluminum, silicon, potassium and other elements in small amounts. We can observe defects in the microstructure of the rubber, presented by holes and microclusters.

\section{CONCLUSIONS}

In this paper was presented a study on using the scanning electron microscope (SEM) with EDS system, we studied the surface structure of different type of rubbers and identified the additives used on them. From the analysis of BSE images was highlighted the basic matrix of rubber. Different shapes and sizes of particles of additives were spread on the whole surface (and therefore volume) of rubber.

Except the chemical analysis of the additives, we can observe defects in the microstructure of the rubber, presented by holes and microclusters.

Analyzing the EDX spectra, we identified the main additives, such as them influence the processing of recycled rubbers also, influence the physic mechanical properties, and the appearance of the rubbers.

\section{REFERENCES}

[1] M.Adamiak (2012) Abrasion resistance of materials. Edited by Dr Marcin Adamiak, Publisher InTech, Tirana.

[2] L.Alessandria, D.Scozia, R.Bono, G.Gilli (2013) Artificial turf football fields: environmental and mutagenicity assessment, Arch Environ Contam Toxicol, 64,1-11.

[3] R.David, Sc.Brow (2007) Artificial Turf Environment \& Human Health, Inc(downloaded from the internet date:10.03.2016).

[4] G.H.Michler (2008) Electron microscopy of polymers, book, Springer, Berlin.

[5] A.Turer (2012) Recycling of scrap tires. Material recycling - trends and perspectives, edited by Dimitris S. Achilias, Publisher InTech, Tirana.

[6] L.Claudio (2008) Synthetic Turf HIth Debate Takes Root, Environmental Health Perspectives, 116(3), 56-64.

[7] O.Guise, C.Strom, P.Nisha (2011) STEM-in-SEM method for morphology analysis of polymer systems, Elsevier, Geneva.

[8] V.C.Chandrasekaran (2012) Essential rubber formulary: formulas for practitioners, book, Publisher InTech, Tirana.

[9] J. E. Mark (1999) Polymer data handbook, Elsevier, Geneva.

[10] S.Dennis, S.Kostick (2010) Minerals Yearbook-Salt, book, Publisher InTech, Tirana.

\section{IZVOD}

\section{MORFOLOŠKA I HEMIJSKA STUDIJA RECIKLIRANIH OPILJAKA SINTETIČKE GUME POMOĆU SEM I EDX}

Ovaj rad ima za cilj da istraži strukturu i hemiju recikliranih opiljaka sintetičkih guma. Sastoji se od mikroskopske strukture gume, razdvajanja faza komponenti i određivanja hemijskih elemenata aditiva koji su korišćeni. Za tu svrhu korišćen je skenirajući elektronski mikroskop (SEM), tip JEOL6380LV, opremljen sistemom EDS. Uzorci gume su sakupljani na različitim mini fudbalskim terenima u Albaniji, koji koriste sintetičku veštačku travu i gde se guma koristi kao punioc, povećavajući stabilnost i elastične osobine sintetičke trave. Uzorci gume su analizirani kao mrvice, dobijene u polju. Crumb metal ispuna je održiva bez metala i ne sme da sadrži oslobođena vlakna u količini koja prevazilaze $0,01 \%$ od ukupne težine f crumb gume. Proučavano je sedam različitih uzoraka mrvica reciklirane sintetičke gume. Pomoću slika koje pruža SEM proučavana je mikrostruktura ispitivanih uzoraka. Takođe, nakon analize EDX spektara, uočeni su aditivi u materijalima koji su reciklirani.

KIjučne reči: reciklirana guma, SEM, EDS, sintetička veštačka trava, EDX, aditivi.

Naučni rad

Rad primljen: 12. 03. 2017.

Rad prihvaćen: 26.04 .2017$.

Rad je dostupan na sajtu: www.idk.org.rs/casopis

(C) 2017 Authors. Published by Inženjersko društvo za koroziju. This article is an open access article distributed under the terms and conditions of the Creative Commons Attribution 4.0 International license (https://creativecommons.org/licenses/by/4.0/) 